Social Work

\& Education

(๑) SWRE, 2018

\section{Antonina Kononchuk,}

Ph.D., Associate professor, doctoral candidate Department of Social Work,

Taras Shevchenko Chernihiv

Collegium,

Chernihiv, Ukraine

antoninakononchuk@ukr.net

УДК: 378.147 - 057.81:364.4

DOI: $10.25128 / 2520-6230.18 .2 .6$
Kononchuk, A. (2018). Portfolio technology as a means of forming professional competencies for future social sphere workers, Social Work and Education, Vol. 5, No. 2., pp. 52-65.

\section{PORTFOLIO TECHNOLOGY AS A MEANS OF FORMING PROFESSIONAL COMPETENCIES FOR FUTURE SOCIAL SPHERE WORKERS}

\begin{abstract}
The article reveals the relevance of using new approaches and technologies to the formation of professional competences of future social workers in the process of professional training. The latest research on the definition of "portfolio" in the system of higher education analyzed. The portfolio presented as an innovative pedagogical technology for the formation of professional competences of future social workers. The principles, functions, essential characteristics of the technology are determined. The results of the research on the use of this technology in the process of training future social workers at Nizhyn Mykola Gogol State University within the framework of the study of educational disciplines presented. The possibility and prospects of the use of portfolio technology in preparing future employees of the social sphere in order to form professional competencies are considered.
\end{abstract}

Key words: professional training; professional competence; portfolio technology; evaluation; social workers. 


\section{Introduction}

The creation of a pan-European economic, cultural and educational space, the integration of Ukraine into the European community, the dissemination of information communications, providing virtually unlimited opportunities for information and communication, change the approach to education in general and the professional training of specialists in higher education in particular. The analysis of the conceptual provisions of normative legal documents and modern scientific papers has shown that the purpose of changes in higher education is to create a unified European approach to higher education by different educational means. The training of highly skilled specialists, strengthening their ability to work in the global labor market is the goal of higher education.

Such opportunities today create the introduction of a student-centered learning paradigm based on a competency-based approach. According to this approach, an integrative indicator of the quality of training of future social workers is their professional competence. The professional competence is a dynamic combination of knowledge, skills and practical skills, ways of thinking, professional, ideological and civic qualities, moral and ethical values that determine the ability of a person to successfully carry out professional and further training activity (Law of Ukraine "On Higher Education", 2014).

This requires using innovative educational technologies that are associated with the adoption of a new understanding of the nature of the educational process where the focus is shifting from the result to the process of its creation. Focusing on efforts on self-achievement, and in the context of the general trend intensify the training of students. The independence of their thinking, the ability to analyze their professional activities, the ability to demonstrate the development and competence in the professional area are at the forefront. The conditions that provide sustained formation competence of social workers and social workers as the current and final learning outcomes in higher education. In our opinion, the most successful technology portfolio can take into account modern requirements and ensure the formation of professional competence of social workers during vocational training in high school.

The portfolio technology began to be actively disseminated at the beginning of this century in Ukraine. The term "portfolio or portfolio of educational achievements" is used wider than the term "portfolio" in our country (in particular, pedagogical periodicals widely present the methodology for creating a "student success folder", the teacher's "achievement folders"). Speaking of "folders" or "portfolios of individual educational achievements," often refers to a simple collection of students or a new way of assessing their academic success. In this sense, the elements of the "portfolio of educational achievements" were widely used in native pedagogy at the beginning of the twentieth century, and even earlier. However, this idea was not widely disseminated at the time in the practice of Ukrainian education.

Now the understanding of the essence and forming opportunities of a portfolio as an educational technology, an analysis of the existing experience of its creation by the subjects of pedagogical interaction, an attempt to develop technological aspects of the introduction of foreign experience in Ukrainian higher education (Bakhmat N.V., 2014; Polat E.S., 2002; Romanenko Y.A., 2012 ). We believe that the methodological basis 
for the use of portfolio in the training of future specialists in the social sphere in the modern conditions of modernization of higher education is a competent approach.

In the context of this approach, it became clear that the standard methods for evaluating academic achievements of students, among which the most common is testing, do not allow to fully developing the necessary skills and skills required by a future specialist to provide successful life and professional strategies after graduation. The most commonly used standardized tests cannot assess the students' ability to perform professional tasks in a real life situation. Therefore, the widespread use of tests is a limitation to the development of the most important behavioral skills and key competencies that are now in demand in the professional environment and in everyday life. They are the least aimed at identifying the individual abilities and inclinations of students.

The use of portfolio as the technology of authentic assessment in educational institutions is associated with the United States, which declared itself at the turn of the 70 's and 80's of the twentieth century under the influence of politics and business. Already at the end of the twentieth century, the technology was rapidly spreading in the educational environment of Canada, Europe and Japan, and became as one of the educational trends of the last decade and touched upon the educational and educational process of higher education institutions. The portfolio in education began to use in the last 10-20 years in Ukraine.

The problem of the professional training of social workers and social educators was deal with such Ukrainian scientists: S.Arhipova, O.Bezpalko, R.Vainola, T.Veretenko, I.Dobroskok, L.Zavatska, I.Zvereva, A.Kapska, O.Karpenko, L.Myshchik, V.Polishchuk, A.Rizhanova, L.Tyupta, S.Harchenko and others. Scientists disclose the scientific, methodological and organizational-technological aspects of the professional training of specialists in the social sphere under conditions of continuous education, present the system of general and professional competencies necessary for successful professional activity. They see the improvement of the quality of the professional training of future specialists in the social sphere, in particular, in introducing innovative educational technologies into the educational activity that promote the students' thinking, accustom their professional reflection, scientific research, independent work and organization, and develop creativity, ability to selfdevelopment and self-education.

\section{Discussion}

Many researchers consider one of these technologies as portfolio technology nowadays and actively work on the problem of its implementation in the educational process. Different approaches to the definition of the concept of "portfolio" explored. The relevance of such an innovation in the educational process is substantiated, its varieties and structural features are analyzed (Ya. Belmaz, G.Golub, V.Zagvozdkin, A.Fasol, and others). The methodical aspects of the use of a portfolio in pedagogical activities are studied (N. Bakhmat, L. Vasilchenko, L. Morskaya, I. Rozhniatovskaya, I. Sokolianskaya, etc.), during profile education (T. Novikova, M.Pinska, O.Prutchenko and etc.), distance education (Y.Polat), professional training of specialists (I.Zadorozhna, S.Its, V.Kucheryavets, Y. Romanenko, A.Sidoruk, I.Sokolianskaya, 
A.Fasol, S.Shehavtsova, etc. .) and so on. Ukrainian and foreign scholars consider portfolios in different ways:

- A means of generalization and systematization of pedagogical achievements (V.Kirichenko, etc.);

- A tool for the formation of a teacher's professional competence (A. Kendiukhova, I. Smirnov, and others);

- A means of monitoring the formation of professional competence of a specialist (T.Gorbunova, N. Bakhlova, E.Ignatyeva, E.Kondratenko, E.Semenova, O.Tumasheva, etc.) including the teacher of higher education;

- The method of management of an individual educational trajectory (N.Sivas, E.Tur, etc.);

- The method of authentic (that is, in fact, closest to the real one) evaluation of the educational and cognitive achievements of students (A. Budko, O.Datskiv, Y.Romanenko, T.Sokolianskaya, etc.), etc.

Considerable attention is paid to the problem of using the electronic portfolio $(\mathrm{N}$. Bidyuk, A.Jurinsky, B.Yevtukh, V. Zhukovsky, V.Kovalenko, S.Romanov, etc.), including in the training of future specialists (L.Petrenko, S.Its,), in the educational environment as a means of measuring the performance of the teacher (O. Smolyaninov, N. Shilin, N. Morse, L.Varchenko-Trotsenko, etc.). Relying on educational philosophy with psychological and pedagogical background, a more profound approach considers the use of portfolio as a pedagogical technology, which can serve as a means of forming professional competencies (G. Artemyev, E. Kondratenko, N. Makovetska, H. Podkovo, Y. Romanenko and others). It changes the emphasis in the educational and cognitive activities of the student. Namely: enabling the future specialist to participate in its creation as a self-assessing and continuous process based on the reflection of personal participation, which allows systematically to analyze and argue their own activities, carry out a qualitative assessment of the result, build a plan to further work and increase its efficiency, to change personality successes (to believe in personal success). We consider the use of portfolio in the training of future social workers and social educators in this context. Foreign psychologists and educators also make up significant interest in the study of works: Sh. Beka, R. Berka, R. Brandt, N. Bridzhford, J. Gilbert, Gronlund Norman E., D. Lambadin, K. Mayer, C. Pearson, G. Siyzek, R. Stiigens and others.

The study of scientific literature reveals that the question of the use of a portfolio for the formation of professional competences and assessment of educational outcomes of future social workers in higher education needs to be processed.

The analysis of foreign experience and Ukrainian practice shows that an important tool for solving such educational tasks is the introduction of a new approach to evaluation. The application of an accumulation system of educational achievements, where more attention paid to assessing the performance of tasks by students in natural situations, rather than by applying even the most objective tests. Such a system is "portfolio". It provides an opportunity to approach its future professional creation as a continuous process based on reflection that allows you to systematically analyze your own activities, carry out a qualitative assessment of the result, build a plan for further work and increase its efficiency. 
The analysis of scientific sources in the field of pedagogy convincingly proves that portfolio technology involves the integration of quantitative and qualitative evaluation, the shift of emphasis on achievement, success, student self-esteem, and his own understanding of readiness for professional activity. The traditional portfolio is a collection, an exhibition of works, the purpose of which is to demonstrate the educational achievements of a future specialist, made for a certain period in a university or outside the university. Such an understanding of the content of the portfolio is no longer relevant in view of the current understanding of the essence of the educational process. It's essential complement is evaluation, the main task of which is to track the student's individual progress in learning in the absence of a direct comparison of his achievements with the achievements of others, the addition or replacement of test results, other forms of control. Y.Romanenko remarks: "...when considering a portfolio more than a set of documents or a collection of materials, then we can say about this method as an effective means of objectively assessing their own personal competencies, able to compete in the labor market, rational advancement of future professionals, the promising professional and creative growth of the individual" (Romanenko Y.A., 2012, p.38). It gives grounds to consider the portfolio as an integral component of the educational process in the higher school. We impressed by the point of view of the scholars who believe that the portfolio motivates students to motivate learning achievements, gain experience of business competition, objective justification of selfeducation and development of professional competences, assessment of personality abilities (Gronlund Norman E., 2005).

Consequently, revealing the diverse portfolio's potential during the formation of professional competencies of future specialists in the social sphere is possible thanks to the use of portfolio as a pedagogical technology. Confirmation of our opinion is the correspondence of the portfolio with the features of pedagogical technology. They are: a conceptual, diagnostic determination of goals and effectiveness, efficiency (optimization of the teacher's work and achievement of the planned results in the shortest possible time), algorithmicity, projection, integrity, controllability, correction (the possibility of constant operational feedback which is consistently focused on clearly defined goals), visualization (involves the use of audiovisual and information and computer technologies ics, and the design and application of various teaching materials and original visual aids) (Chepil M.M., 2012).

The essential features of portfolio technology is that it not only provides the educational and cognitive activities of subjects of pedagogical interaction, but also provides an opportunity for reflection and self-evaluation, allows you to design, monitor and correct all stages of the formation of your own professional competence.

Experimental work on the use of portfolio technology as a means of shaping the professional competences of future social educators and social workers conducted during four years (2014-2018) in Nizhyn Mykola Gogol State University. It was using in the process of studying the following disciplines: "Social work with street children", "Socio-pedagogical activity with different categories of the population", "Social work with special categories of clients". In the process of studying such educational disciplines as "Social work with street children", "Socio-pedagogical activity with different categories of the population", "Social work with special categories of clients", 
a complex "Portfolio of the student" was used (meaningfully combining work, documents, reviews).

We concluded that portfolio technology in the professional training of social professionals could be consider effective due to its positive impact on the various types of motivation necessary for a modern student to undertake early professional development. It feeds student authorship on content, the purpose and process of creating various types of work, creative approach to professional growth; is update with the student's efforts to establish correlations between their own professional experience and the relevant professional standards (competencies). This was evidenced by the results of the survey of students, in particular, it was determined that the motivation for the chosen profession from respondents increased by $37 \%$ (from $21 \%$ to $58 \%$ ).

In contemporary foreign and Ukrainian scientific literature devoted to the portfolio of learning, we find a wide range of interpretations of the concept of "portfolio", which gives grounds for a general definition of its essence as a collection of information about the person and the results of her activities, demonstrating efforts, progress and achievements in various spheres, including professional activities. In this aspect - this is a kind of visiting card of a future specialist in practical professional activity, the materialization of his efforts to create his own positive image.

In addition, the idea of a portfolio abroad is associated with a new understanding of the nature of the educational process, with new educational goals. The specifics of the use of a portfolio in the United States is to focus on authentic assessment, which is primarily applied in practice-oriented activities, and involves assessing the formation of skills, personality skills in a situation that is as close as possible to the requirements of the field of professional activity. In the UK, the portfolio presented as an assessment tool that provides an opportunity to evaluate not only the cognitive component of the teacher's competencies, but also to implement a personality-oriented approach in the professional development of professionals. In Germany, for the most part, the accumulation function of the portfolio is used - the portfolio of achievements (Kondratenko E.V. Portfolio of the collection of Chernihiv, 2014).

\section{Methodology of the research}

The purpose of the article is to analyze the theory and practice of using portfolio technology in vocational training (in the process of evaluating educational results and personal achievements, in particular the formation of professional competencies) of future social workers and social educators in a higher education institution. To solve this goal, the general scientific methods of research were applied, in particular, theoretical analysis of scientific sources, comparison, synthesis and generalization of data, as well as empirical, such as studying documentation, interviewing, questioning, designing, rating, generalization of independent characteristics.

Therefore, based on the research of scientists, we define portfolio as an innovative technology of unity (integration) of the development, formation and authentic assessment of professional competence of students in the process of preparation in high school, the level of their general and professional competencies (alumni readiness for professional activity) for a certain period of study. The meaningful and procedural process is the prolonged process of comprehension, 
definition (fixing), planning, measurement, stimulation, accumulation, control and evaluation of the results of personal educational, cognitive, creative, social and other activities, development of their own personal competencies, efforts, progress and achievements of the student. In the chosen professional field through the prism of selfknowledge, self-esteem, reflection, self-organization, self-control, self-examination of their achievements, analysis, argumentation and planning of their own actions, decisions, methods self-development and self-presentation of personality both in higher educational establishments, and in the future professional and business environment. Today we have a materialized portfolio displaying in the form of a properly organized and selected for a certain purpose a formalized set of documentary materials of the owner (self-executed works, reports, certificates, publications, certificates, attributes, normative documents, photographs, video materials, etc.) in a paper (folder, a set of materials) and in electronic form, including a web portfolio.

The goal of introducing portfolio technology into the process of training future social workers and social educators is to stimulate the need for personal and professional self-development and self-improvement, increasing motivation for study. The main task is to promote the acquisition of skills and skills to create a positive professional image, self-presentation, and thereby enhance the competitiveness of the future specialist, his professional and personal self-realization based on the establishment of an individualized vector of development of professional competencies.

The overall goal of introducing portfolio technology into the process of training future social workers and social educators was to stimulate the need for personal and professional self-development and self-improvement, enhancing motivation for learning; the main tasks - to help master the skills and abilities of "portfolio" technology, create a positive professional image, self-presentation and thereby enhance the competitiveness of the future specialist, his professional and personal selfrealization on the basis of the establishment of an individualized vector of development of professional competencies. The target sample was made by bachelors and masters with a total of 67 people.

Methodology of research (technology implementation) was that the students, according to the teacher's assignment, selected their "Individual portfolios" documents, reviews, work performed by them on their own, both at classes and during extracurricular time. The selection was conducted from each specified discipline during its study according to the curriculum (semester, academic year) and was accompanied by reasoned explanations of the students, why they consider it necessary to include these documents, work, reviews. Students had to record and confirm each achievement. The instructor acquaints students with the requirements for organization of work, structuring the content of the portfolio, criteria for evaluation. The main thing in this work is the self-esteem of a student in the form of considerations, arguments, and justifications. Upon completion of the work, students presented their portfolios to the group, where everyone showed their progress in the work on the learning of the subject and argued that he made the maximum effort. As a result, his self-esteem coincided or did not coincide with the assessment of a teacher and a group of experts from among the students. An important point in the presentation was the student's defense of his achievements, an understanding of what the self-esteem and external evaluation 
coincide, and in what - no, conclusions about his further cognitive and creative activity in this direction.

To evaluate the students' work on the creation of the "Individual portfolio" and the final evaluation, we used a four-tier system that was established in the practice of American educational institutions (according to the following criteria: structuring, content, development, motivation, argumentation, presentation, etc.) and correlated with the national scale ECTS grading.

The highest level (excellent; 90-100 points). The clearly structured content of the portfolio illustrates the great efforts made and the obvious progress of the student in developing his thinking, applied and communicative skills, the existence of a high level of self-esteem and creative attitude to the subject, that is, the development of professional competence. In the content that covers the entire program, and the design of the training portfolio is clearly manifested in originality and ingenuity. Selfassessment of the results is justified. The thematic diversity and completeness of submitted materials, aesthetics, visibility and validity of the presentation are demonstrated.

High level (well; 74-89 points). "Portfolio" of this level demonstrates sufficient professional knowledge and skills in the discipline, shows progress in professional development for a certain period, a creative element in the structuring and design of the portfolio, originality in its content, but it may lack some elements of the optional components marked in the curriculum. The self-assessment of the results is based on supporting documents. The thematic variety of presented materials, the visibility and validity of the presentation are demonstrated.

Average level (satisfactory, 60-73 points). In the portfolio of this level, the main emphasis is on the compulsory component noted in the curriculum, which allows you to assess the level of the formation of professional knowledge and skills. There is no evidence that demonstrates the level of development of creative subject thinking, professional skills, skills, ability to meaningful communication. There are no separate components in the portfolio structure. The presentation does not fully demonstrate the materials, it requires self-evaluation of the results.

Low level (unsatisfactory; 1-59 points). Quite a non-informative, unsystematic, unstructured "portfolio", which makes it difficult to form a general idea of the student's professional development. As a rule, here are presented separate fragmentary materials from different parts of the curriculum, separate sheets with incomplete tasks and exercises, individual supporting documents. For such a "portfolio" it is virtually impossible to determine the progress in education and the level of formation of professional competences reflecting the main purpose of the subject.

\section{Results}

We concluded that portfolio technology in the professional training of social professionals could be consider effective due to its positive impact on the various types of motivation necessary for a modern student to undertake early professional development. It feeds student authorship on content, the purpose and process of creating various types of work, creative approach to professional growth; is update with the student's efforts to establish correlations between their own professional experience 
and the relevant professional standards (competencies). This was evidenced by the results of the survey of students, in particular, it was determined that the motivation for the chosen profession from respondents increased by $37 \%$ (from $21 \%$ to $58 \%$ ).

The external and internal aspects of the designation of a portfolio should be taken into account (individual scientists define them as principles), and they must create conditions for their implementation. External to familiarize others (teachers, students, parents, supervisors, etc.) with the achievements and progress of the individual, assessing the significance of these achievements, determining the peculiarities of the student's activity for the proper construction of the educational process. Internal for the development of the student's own personality and the achievement of further results in professional training in the context of enhancing motivation and developing more accurate ideas about their own successes, disadvantages and opportunities. Therefore, the portfolio allows solving three main tasks:

1) To trace the individual progress achieved by the student in the process of vocational education;

2) Evaluate the efforts and educational achievements of the student, readiness for a professional career and supplement (replace) the results of testing and other traditional forms of control;

3) Distinguish the range of skills and abilities of the student who demonstrate his competitive advantages during employment.

During the research, we implemented the portfolio functions identified by the researchers and that were relevant for the training of future social workers, namely: diagnostic, prognostic, managerial, organizational, informational, analytical, pedagogical, goal-setting, motivational, informative, developmental, rating and adaptation (Romanenko Y.A., 2012, p. 38). For example, as a means of evaluating those who study, the portfolio performs the following functions:

diagnostic (records the progress in learning for a certain period);

goal-setting (helps to develop the ability to set goals and control their achievements);

motivational (encourages students to work systematically);

content (covers almost the entire content of the course program);

developing (provides continuity of learning and development);

rating (showing the level of formation and range of student skills and abilities).

The portfolio implements the following main functions as a professional business card:

presentation (demonstrating skills and abilities to create an attractive personal and professional image, to create a positive impression and interest);

reflexive (materializes the results of comprehension, systematization and structuring of own achievements for the solution of specific tasks, for example, to present their own achievements to less experienced colleagues, parents, and teacher);

fixative (documented the process of accumulation, assessment and selfassessment of individual life and educational achievements of a future specialist in the chosen profession).

The mastering portfolio technology depends on the type of portfolio chosen for the learning process and may include the following components: 
1)compilation of the annotated list of literature on the topic;

2)writing a review or reviewing materials that have caused professional and personal interest;

3)study of actual social problems of certain categories of users of social services;

4)solution of situations;

5)development of programs and projects;

6)a collection of various design, creative, research, educational achievements, etc.

The research has shown the effectiveness of using such types of portfolios: portfolio of documents, portfolio of works and portfolio of reviews.

The question of portfolio assessment, which we solved through the formalization and standardization of evaluation criteria, agreed with the generally accepted high school performance, turned out to be rather complicated. It needs to take into account the following points : it is necessary to determine the range of evaluation ; different elements of the portfolio may simply be incomparable and it will be difficult to estimate the shares of their contribution ; today there is a real contradiction between the theoretical orientation of the portfolio and the qualitative and quantitative assessment and the requirement to take into account educational achievements in the standard quantitative form (placement of ratings).

Formalizing the portfolio evaluation process helps to classify (define categories) of its components and determine the system of distribution of points. For example:

Compulsory: intermediate and final written independent and control works;

Research: the implementation of complex projects (both individual and small groups), the study of a complex problem, the solving of non-standard tasks of increased complexity;

Situational: application of the studied material in practical situations, for solving applied tasks, performing graphic and laboratory works;

Descriptive: compilation of a subject autobiography, keeping a subject diary, writing essay essays and works;

External: testimonials by teachers, fellow students, parents, as well as teacher letters of verification (Rice J.M., 2004, p.241-243).

The distribution of points can be as follows: mandatory category - $40 \%$, search $30 \%$, situational - $15 \%$, descriptive - 10\%, external - 5\% (with the corresponding distribution of scores on the ECTS grading scale and the national system). The total score for the portfolio can define as the sum of the maximum points for each category.

We should remember that the portfolio of a future employee of the social sphere, as well as any portfolio in general, is individual in nature. It consists of the professional-psychological characteristics of only its author, and work on portfolio contributes to the formation of an individual style of activity, methodical culture and modern professional thinking, raising the criticality in the self-assessment of professional activity.

\section{Conclusion}

Consequently, in foreign and Ukrainian educational studies, the portfolio considers as a technology oriented to the result of activities it based on a competent 
approach and allows developing professional competencies of students and assessing the level of their formation at different levels and levels of professional training. We see an understanding of portfolio technology and the fact that it can also serve as a means of building the competencies. Portfolio as a multifunctional technology confirms the effectiveness of its use in professional training of specialists in the social sphere in higher education. Taking into account modern requirements of society and European integration changes in the system of higher education, it will allow raising the level of their professional competence qualitatively. Further perspectives of scientific work we see in the study of problematic vectors of the use of portfolio technology and the development of methodological recommendations for their overcoming in the process of training future specialists in the social sphere.

\section{References}

Gronlund Norman E. (2005). Student Performance Assessment: A Practical Guide / E. Norman Gronlund. K .: Educational Center "Consortium for the Improvement of Management Education in Ukraine", 312 [in Ukrainian].

The Law of Ukraine "About the Illness of the Osvit" [Electronic resource]. Access mode: http://zakon4.rada.gov.ua//laws/show/1556-18/page. [in Ukrainian].

Kondratenko, E. V. (2014). Portfolio as a technology for assessing the professional competencies of students. Bulletin of the Mari State University. №1(13), 176-180 [in Russian].

Modeling of a teacher's portfolio: teaching method-manual / method. N.V. Bakhmat. 2nd kind, reworked. and complemented Kamyanets-Podilsky, 2014, 72 [in Ukrainian].

New pedagogical and information technologies in the education system / E.S.Polat, M.Yu.Bukharkina, M.V. Moiseeva, A.E.Petrov; Ed. E.S. Polat. M.: Academy, 2002, 272 [in Russian].

Assessment and selection of pedagogical innovations: theoretical and applied aspect: scientific method. manual / ed. L. Danilenko. K.: The Logos, 2001, 185 [in Ukrainian].

Portfolio of teacher / red. I. Sokolianskaya. Kharkiv: View. Group "Basis", 2013, 224 [in Ukrainian].

Romanenko, Uy. A. (2012). Portfolio of the student: didactic aspect. Scientific notes of the NDU named by M.Gogol. Psychological-pedagogical sciences. №2, 38-40 [in Ukrainian].

Sydoruk, A. V. (2015). Use of portfolio technology in assessing the readiness of future teachers of physical culture. Pedagogical sciences: theory, history, innovative technologies. Sumy: Sumy MPU named after AS Makarenko. №8(52), 186-192 [in Ukrainian].

Chapil, M. M. (2012). Pedagogical Technologies: teaching manual. K.: Academic Edition, 224 [in Ukrainian].

Carless, D., Joughin, G. \& Mok, M. (2006). Learning-oriented assessment: principles and practice, Assessment and Evaluation in Higher Education. №31(4), 395-398.

Ebel, R. L. (2005). Measuring Educational Achievements. N. J. : Prentice Hall, 481.

Rice, J. M. (2004). 50 years of objective measurement and research in education of Educational Research. № 41, 241-264. 
Gronlund Norman, E. (2005). Evaluation of Student Performance: A Practical Guide. K.: Educational Center "Consortium for the Improvement of Management Education in Ukraine".

Law of Ukraine "On Higher Education" [Electronic resource]: http://zakon4.rada.gov.ua//laws/show/1556-18/page.

Kondratenko, E.V. (2014). Portfolio as a technology for assessing the professional competencies of students. Bulletin of the Mari State University. 1(13), 176-180.

Bakhmat, N.V. (2014) Modeling of a teacher's portfolio: teaching method-manual. Kamyanets-Podilsky: Buynitsky A. A.

Polat, E.S., Bukharkina, M.Yu., Moiseeva, M.V., Petrov A.E. (2002) New pedagogical and information technologies in the education system. M.: Academy.

Assessment and selection of pedagogical innovations: theoretical and applied aspect: scientific method manual. (2001). K.: Logos.

Sokolianskaya, I.T. (2013). Portfolio teacher. Kharkiv: View. Group "Basis".

Romanenko, Y.A. (2012). Portfolio of the student: didactic aspect. Scientific notes of the N.G. Psychological-pedagogical sciences. 2, 38-40.

Sidoruk, A.V. (2015). The use of portfolio technology in assessing the readiness of future teachers of physical culture. Pedagogical sciences: theory, history, innovative technologies. Sumy: Sumy MPU named after A.S.Makarenko. 8 (52), 186-192. Edition.

Chepil, M.M. (2012). Pedagogical Technologies: Teach manual. K.: Academic

Carless, D., Joughin, G. \& Mok, M. (2006). Learning-oriented assessment: principles and practice. Assessment and Evaluation in Higher Education. 31(4), 395-398.

Ebel, R. L. (2005). Measuring Educational Achievements. N. J. : Prentice Hall.

Rice, J. M. (2004). 50 years of objective measurement and research in education of Educational Research. 41, 241-264. 


\title{
ТЕХНОЛОГІЯ ПОРТФОЛІО ЯК ЗАСІБ ФОРМУВАННЯ ПРОФЕСІЙНИХ КОМПЕТЕНТНОСТЕЙ МАЙБУТНІХ ПРАЦІВНИКІВ СОЦІАЛЬНОЇ СФЕРИ
}

\author{
Антоніна Конончук, кандидат педагогічних наук, \\ доиент, докторант кафедри соиіальної роботи, \\ Наиіональний педагогічний університет «Чернігівськкий колегіум \\ імені Т.Г. Шевченка» м. Чернігів, Украӥна \\ antonina_kononchuk@ukr.net
}

Анотація. У статті розкривається актуальність використання нових підходів та технологій до формування фахових компетентностей майбутніх прачівників сочіальної сфери у процесі професійної підготовки. Проаналізовано останні дослідження щодо визначення поняття «портфоліо» в системі вищої освіти. Схарактеризовано портфоліо як інноваційну педагогічну технологію формування професійних компетентностей майбутніх працівників соиіальної сфери. Визначено принципи, функиії, суттєві характеристики технології. Наведено результати дослідження щодо використання даної технології у процесі професійної підготовки майбутніх соиіальних праиівників у Ніжинському державному університеті імені Миколи Гоголя у межсах вивчення навчальних дисииплін "Сочіальна робота з дітьми вулиці», «Соиіально-педагогічна діяльність з різними категоріями населення», «Соціальна робота з особливими категоріями клієнтів». Розглянуто можливість та перспективи використання технології портфоліо у підготовиі майбутніх працівників соціальної сфери з метою формування професійних компетентностей.

Ключові слова : професійна підготовка, професійні компетентності, технологія портфоліо, оцінювання, прачівники соціальної сфери

\section{Література}

Гронлунд Норман Е. (2005). Оцінювання студентської успішності: практичний посібник / Е. Норман Гронлунд. К. : Навчально-методичний центр «Консорціум із удосконалення менеджмент-освіти в Україні», 312.

Закон України «Про вищу освіту» [Електронний ресурс ]. Режим доступу : http://zakon4.rada.gov.ua//laws/show/1556-18/page.

Кондратенко, Е. В. (2014). Портфолио как технология оценивания профессиональных компетентностей студентов. Вестник Марийского государственного университерта. №1(13), 176-180.

Моделювання портфоліо педагога : навч.-метод.посібник / уклад. Н.В.Бахмат. 2е вид., переробл. і доповн. Кам'янець-Подільський : ПП Буйницький А.А., 2014. 72.

Новые педагогические и информационные технологии в системе образования / Е.С.Полат, М.Ю.Бухаркина, М.В.Моисеева, А.Е.Петров ; под ред. Е.С.Полат. М. : Академия, 2002. 272. 
Оцінювання та відбір педагогічних інновацій : теоретико-прикладний аспект : науково-метод. посібник / за ред. Л.Даниленко. К. : Логос, 2001. 185.

Портфоліо педагога / укл. І.Т.Соколянська. Харків : Вид.група «Основа», 2013. 224c.

Романенко Ю.А. Портфоліо студента : дидактичний аспект / Ю.А.Романенко // Наукові записки НДУ імені М.Гоголя. Психолого-педагогічні науки. - 2012. №2, 38-40.

Сидорук, А. В. (2015). Використання технології портфоліо в оцінюванні готовності майбутніх учителів фізичної культури. Педагогічні науки : теорія, історія, інноваційні технології. Суми : СумДПУ імені А.С.Макаренка. №8(52), 186-192.

Чепіль, М. М. (2012). Педагогічні технології : навч. посіб. К. : Академвидав, 224.

Carless, D., Joughin, G. \& Mok, M. (2006). Learning-oriented assessment: principles and practice, Assessment and Evaluation in Higher Education. №31(4), 395-398.

Ebel, R. L. (2005). Measuring Educational Achievements. N. J. : Prentice Hall, 481.

Rice, J. M. (2004). 50 years of objective measurement and research in education of Educational Research. № 41, 241-264.

Gronlund Norman, E. (2005). Evaluation of Student Performance: A Practical Guide. K.: Educational Center "Consortium for the Improvement of Management Education in Ukraine".

Law of Ukraine "On Higher Education" [Electronic resource]: http://zakon4.rada.gov.ua//laws/show/1556-18/page.

Kondratenko, E.V. (2014). Portfolio as a technology for assessing the professional competencies of students. Bulletin of the Mari State University. 1(13), 176-180.

Bakhmat, N.V. (2014) Modeling of a teacher's portfolio: teaching method-manual. Kamyanets-Podilsky: Buynitsky A. A.

Polat, E.S., Bukharkina, M.Yu., Moiseeva, M.V., Petrov A.E. (2002) New pedagogical and information technologies in the education system. M.: Academy.

Assessment and selection of pedagogical innovations: theoretical and applied aspect: scientific method manual. (2001). K.: Logos.

Sokolianskaya, I.T. (2013). Portfolio teacher. Kharkiv: View. Group "Basis".

Romanenko, Y.A. (2012). Portfolio of the student: didactic aspect. Scientific notes of the N.G. Psychological-pedagogical sciences. 2, 38-40.

Sidoruk, A.V. (2015). The use of portfolio technology in assessing the readiness of future teachers of physical culture. Pedagogical sciences: theory, history, innovative technologies. Sumy: Sumy MPU named after A.S.Makarenko. 8 (52), 186-192. Edition.

Chepil, M.M. (2012). Pedagogical Technologies: Teach manual. K.: Academic

Carless, D., Joughin, G. \& Mok, M. (2006). Learning-oriented assessment: principles and practice. Assessment and Evaluation in Higher Education. 31(4), 395-398.

Ebel, R. L. (2005). Measuring Educational Achievements. N. J. : Prentice Hall.

Rice, J. M. (2004). 50 years of objective measurement and research in education of Educational Research. 41, 241-264.

Стаття надійшла в редакцію 10 травня 2018 р. 